\title{
THE BURDEN OF GLOBALIZATION
}

\author{
Diasporic Dimensions in Peter Bacho's Cebu
}

and Elaine Castillo's America Is Not the Heart

\author{
Hope Sabanpan-Yu \\ University of San Carlos \\ hsyu@usc.edu.ph
}

\begin{abstract}
This paper explores the experience of diasporic mobility in contemporary Philippine-American fiction. In novels such as Cebu by Peter Bacho and America Is Not the Heart by Elaine Castillo, issues of culture and identity are not only foregrounded but also resignified as diasporic people encounter different situations where their sexuality, religion, gender, language and economic status realign along diverse ways and affect their lives in the new country. In a global community where diasporic experiences are provisional, one is able to explore more attentively how mobility changes, and continues to change, its nature and disrupt stable constructs of identity.
\end{abstract}

\section{Keywords}

literary liquidity, sexuality, religion, gender, mobilities, diaspora

\section{About the Author}

Hope Sabanpan-Yu is professor of literature at the University of San Carlos. She is also the director of the Cebuano Studies Center and Chair of the Division of Humanities of the National Research Council of the Philippines (NRCP). 
Jana Braziel and Anita Mannur write in Theorizing Diaspora a call for scholars to go beyond theorizing how "diasporic identities are constructed and consolidated" and interrogate how diasporic identities are "practiced, lived, and experienced" (9). This paper develops out of the need to find a new way to describe migrant experiences that demonstrates mobile features yet are not considered diasporic. It will also show how the term "diasporic" has gained meaning beyond the traditional definition (usually conflated with "transnational") and cannot explain the sociopolitical, economic, religious, sexual, and gender differences that recent migrants contend with.

To address these differences, diaspora should not be seen as static but as a provisional position. Because of the greatly expanded diasporic features, the interaction between identity factors like ethnicity, language, religion, and sexuality ought to be considered to discover new ways of describing experiences of American subjectivity.

\section{DIASPORA AND ITS PERMUTATIONS}

Diaspora, from the Greek term diaspeirō, connects the terms dia, meaning "from one end to the other," and speiröii, meaning "to sow, to scatter" (Vertovec 129), largely referring to the Jewish experience. Stephane Dufoix explains that originally "diaspora" meant the threat of dispersion facing the Hebrews if they failed to obey God's will. This had applied to almost exclusively divine acts. It was only later in Jewish tradition that the meaning changed to designate both the scattered people and the locale of their dispersion (Dufoix 4). In the last three decades, the term "diaspora" has expanded to constitute a number of experiences: the diffusion of ethnic communities, minorities oppressed within their own homeland, guestworkers, and business executives who temporarily live outside the country where they reside, to cite a few. Some ask if immigrants who voluntarily migrate to another country should be considered diasporic.

William Safran distinguishes between immigrants and diasporic people. He observes that diasporas represent "the leading edge of globalization" since they are not only minority communities:

[T] heir members have moved around-that is, have emigrated from their native countries to other countries. This, of course, can be said of immigrants as such; but diasporas comprise special kinds of immigrants because they have retained a memory of, a cultural connection with, and a general orientation toward their homelands; they have institutions reflecting something of a homeland; they harbor doubts about their 
full acceptance by the hostland; they are committed to their survival as a distinct community; and many of them have retained a myth of return. (Safran 10)

Diasporic people share sociocultural values and constantly look towards their mother country. Robin Cohen recognizes new categories of diasporas: victim (Jewish, Armenian, and African), imperial (British), labor (Indians), trading (Chinese and Lebanese), and cultural (Caribbean). ${ }^{1}$ Both Cohen and Safran emphasize the cultural, economic, and political commitment of diasporas to their idealized homeland and their yearnings to return to their original home. Cohen imagines the possibility that diasporas might prosper in the host country. Safran, on the other hand, only focuses on the difficulties of settling in a new country. Despite the revolutionary works by Safran and Cohen, Robbie Goh and Shawn Wong observe the studies "tend to regard diasporas as mechanistic, static, and divisive" (2). To focus simply on the flow of migration and their restrictions limits diaspora to "a set of systemic causes ... played out in various oppositional terms such as 'home' and 'alien place' ... notions which come under the most pressure in contemporary transnational conditions" (Goh and Wong 3). Diasporas evolve or their members assimilate in their host country.

"Transnationalism" is a term that is often collapsed with diaspora. In Nations Unbound, Linda Basch et al. define transnationalism as

the processes by which immigrants forge and sustain multi-stranded social relations that link together their societies of origin and settlement. We call these processes transnationalism to emphasize that many immigrants today build social fields that cross geographic, cultural, and political borders. Immigrants who develop and maintain multiple relationships-familial, economic, social, organizational, religious, and political-that span borders we call "transmigrants." (Basch et al. 7)

Basch et al. emphasize the relationship between the migrants' homeland and hostland. They use the term "country of settlement" instead of hostland since the latter presumes that the country where the migrants settle down will accept strangers.

Stephane Vertovec provides an expanded definition of transnationalism as

sustained linkages and ongoing exchanges among non-state actors based across national borders-businesses, non-government organizations, and individuals sharing the same interests (by way of criteria such as religious beliefs, common cultural and geographic origins). (Vertovec 3 )

Kritika Kultura 35 (2020): 182-193

(C) Ateneo de Manila University

<http://journals.ateneo.edu/ojs/kk/> 
Aihwa Ong defines "transnationalism" as referring to "the cultural specificities of global processes, tracing the multiplicity of the uses and conceptions of 'culture" (4). For example, in Asia, Chinese entrepreneurs practice "flexible citizenship" since "the cultural logics of capitalist accumulation, travel, and displacement . . . induce subjects to respond fluidly and opportunistically to changing political-economic conditions" (Ong 6). For instance, some people have dual citizenship, and children might have parents living in separate countries. According to Ong, under late capitalist conditions, individuals embrace this transnationality rather than choosing to simply settle down in one place.

In their transnational journey, diasporic subjects join organized communities that perform according to rules established over time. We must ask how they function in the sociopolitical life of the host country; what features of the new culture they will accept and refuse. Avtar Brah states that "all diasporic journeys are composite ... They are embarked upon, lived, and re-lived through multiple modalities: modalities, for example, of gender, race, class, religion, language and generation" (Brah 184). Identities of diasporic people are resignified as they encounter different situations where their sexuality, religion, gender, language, and economic status realign along diverse ways, and these adjustments unquestionably affect the way they behave in the new country. Conflicts between women in diaspora and tradition for instance result in an evolving construction of gender.

For in the complex encounters between transnational capital and women within patriarchal gender structures, the very processes that produce a racialized feminized proletariat both displace traditional and national patriarchies and their defining regulations of gender, space, and work and racialize the women in relation to other racialized groups. These displacements produce new possibilities precisely because they have led to a breakdown and a reformulation of the categories of nation, race, class, and gender.

(Lowe 161-162)

Kandice Chuh shows that identity formation is affected by transnationalism: "The immigrant as descriptor rhetorically references that position of being both of and not of-that transnational space that cannot be singly located in space and time" (292). By focusing on the immigrant instead of the assimilated citizen, Chuh argues that American cultural studies is "reconfigured to accept axiomatically difference and mutability" and transnationalism paves the way to understanding "the incompleteness of narratives of national identity formation" (292). Although Chuh proposes to erase race and nationality as grounds on which Asian Americans negotiate their subjectivity (as she believes a national subject is no longer a possibility for Asian Americans), it benefits to study the interaction of other aspects of identity, such as gender, sexuality, and class to expand the ways to discuss AsianAmerican identity. 
To illustrate my argument, I analyze two novels: America Is Not the Heart (2018) by Elaine Castillo and Cebu (1991) by Peter Bacho.

\section{EXPLORING DIASPORIC DIMENSIONS: INTERACTIONS OF RELIGION, SEXUALITY, CLASS, AND ETHNICITY}

Cebu is a novel about a Filipino-American priest, Ben Lucero, the son of a Filipina mother and a Filipino-American father, who visits the Philippines for the first time when his mother passes away. Ben brings his mother's remains back to Cebu to be buried. In the Philippines he stays with "Aunt" Clara Natividad, his mother's best friend from childhood. Clara has become a wealthy and powerful businesswoman through her uncle's investment in the Japanese occupation and in the Jeeps left behind by the American troops. This jeepney business makes her very rich and gives her the capital to go into "smuggling, assorted vices, and politics" (Bacho 22). Clara earns her fortune through suspicious commercial practice, "taking advantage of cycles of social debt to boost her own success" (Patterson 167).

The novel follows Ben's encounters with Filipino tradition and culture as he travels to both Manila and Cebu. In Manila, Ben spends time with Ellen Labrado, Clara's assistant. It is also in Manila where he witnesses the violence around him, like the Filipino soldiers attacking fellow Filipinos while they protest at the United States Embassy. This leads him to desire his return to Seattle because Ben finds he does not have the stomach for such things. At home in Seattle, Ben still cannot escape the violence as the Filipino immigrant community in his parish is also caught up in gang wars.

Issues of religion, sexuality, and Ben's Filipino ethnicity are brought into sharp focus in several parts of the novel. His religious beliefs are put to the test when he finds out that the decomposing body of Carlito, one of his Aunt Clara's employees, was crucified. As a Catholic priest, the man's crucifixion destroys his belief of the Catholic faith as a unified religion. ${ }^{2}$ Earlier they had been looking for Carlito, but he was nowhere to be found until Marites tells them about how Carlito wanted to go to the Toledo Road.

\footnotetext{
"I'm not sure. It's just a place in the woods by the Toledo Road. And then this morning, on the way over here, I heard about this crucifixion."

"A what?" The priest entered the conversation for the first time.

"Nothing, Ben," Clara said, her tone dismissing the topic. "It's just every Easter, some religious fanatics have themselves stapled to the cross."
}

Kritika Kultura 35 (2020): 184-193

(C) Ateneo de Manila University

<http://journals.ateneo.edu/ojs/kk/> 
Ben's curiosity slowly gave way to anger. "That's not Catholicism. What about the bishop?" (Bacho 76)

What Ben finds confuses him and makes him ask questions about his role within the Church and within society. The reaction of other people to Carlito's crucifixion was that it did not concern them. Some saw it as a joke-that Carlito may have been mentally unstable. Ben is appalled when he learns that the bishop approves of the practice; even if the Lenten practice is an indigenized exercise, it still promotes Catholic values.

Ben also cannot accept the way the Catholic faith is interpreted in the act of crucifixion. There are people who make religious vows in the hope that God will help them save a family member from dying, and imitators of Christ like Carlito think that by crucifying themselves they can indeed save their loved ones-Carlito wanted to save his niece from leukemia. Further, Ben also wonders why photographs of the dead man are being sold-what possible good would that bring a buyer? Debora Stefani writes that

Through death Carlito acquires sanctity. His photo most likely resembles the Renaissance paintings of a suffering Sebastian. Yet, while for the Church the pictures of saints are mere representations, for Filipinos they acquire a value of their own. . . . In Bacho's novel, there is no mentioning of Carlito's image having supernatural faculties, but given the cult for the Ama in Bicol and for other statues in other parts of Luzon, it is safe to conclude that the picture of Carlito's crucified body is indeed endowed with powers. The fact that it is being sold and people are willing to pay for it confirms my assumption that the image might have more value than a regular picture of a dead person-one of the deceased in a coffin. Moreover, one cannot help but noticing that, through death, Carlito has ceased to be a human being and has become a commodity. He has acquired exchange value. (Stefani 99)

The commodity of the photograph (Bacho 88) validates Ben's fears that the priests in the Philippines have lost power as those deemed "sainted" persons have powers that can be purchased with money like any amulet.

The intersection of sexuality and ethnicity is another aspect of identity that we can examine in the novel as causing an existential crisis in Ben. He is a devoted Catholic priest who has a sexual encounter with Ellen, a Filipina-American former prostitute who currently works for his aunt. Ellen is described as mestiza-a tall and beautiful woman with green eyes and brown skin. That she is tall implies her mixed race. The encounter is actually Ben's first foray into sex, since he is a virgin. The other mention of Ben's sexuality in the novel is his dry-humping when he is not in the seminary. 
"You missed," she says. "You're on my thigh, on the sheet, and if I turn on the light, you're probably on that too."

"Shit," comes the embarrassed response.

"It's OK," she says, her voice now warm and reassuring. "You're new at this; but the night's long, your cock's nice, and I have time. Call it my part for education." (Bacho 123)

Prior to being intimate with Ellen, Ben believed that Filipinos are primitive-they are dog-eating and prone to fighting. up in the States, Ben heard the story often enough.

It was part of the legend brought back by American troops after they conquered the Philippines in 1902-Filipinos and dogs, dogs and Filipinos. The relationship shocked soldiers who, in the defense of canines, slaughtered Filipinos like the dogs the natives ate. (Bacho 102)

During Ellen's fight with Anita, Ben himself enthusiastically eggs her on to fight because he still believed Filipinos were violent.

\footnotetext{
"Charge her!" he heard himself advise in a loud voice which, in quick retrospect, embarrassed him. And charge her, she did, slipping the next jab off the side of her head as she moved in. Ellen's momentum carried her low into Anita, toppling both to the ground. Ellen was on top, but the other woman had managed to grab her hair and pull her forward, smothering the effect of her punches. (Bacho 118)
}

For Ben, his affair with Ellen proves his genuine fear that he is really Filipino. Ben has tried to resist being Filipino all his life. He participated in taunting fresh Philippine immigrants when he was a student. He believed that Filipinos were troublemakers and not worthy of becoming Americans. After having sex with Ellen, he dreams that his psychology professor berates him and tells him Filipinos have no control over themselves, suggesting a deep-seated anxiety over his ancestry.

Ben returns to Seattle feeling he has completely recovered his faith and his training, even though he distances himself from the recent Filipino immigrants who settle there. This distancing also shows his discomfort at being associated with how he perceives Filipinos to be-"rowdy and ... wreak different types and degrees of juvenile havoc" (Bacho 107). Towards the end of Cebu, Ben has another opportunity to prove he is indeed a priest when a young Filipino confesses to having murdered someone. The young man demands absolution but Ben refuses to absolve the Filipino. Ben has bought into the American prejudice that Filipinos are inferior. His dark skin, however, marks him as Filipino and assigns meaning to his body as 
normative of that of a Filipino. Ben faces an existential dilemma of who he really is: he wants to be American, but is physically marked as Filipino.

In this section I will examine how the modalities of ethnicity, sexuality, and gender intersect in America Is Not the Heart (2018) by Elaine Castillo. The novel's title is a play on Carlos Bulosan's America Is in the Heart (1946) which portrays the experiences of immigrant and working-class Filipinos in the United States who search for the promise of a better life. Castillo's novel opens with the narration of Paz's life in the second person and how as a child, she scrapes whatever food she could find; saves some money to get a gold tooth, only to have all her good teeth fall out because of the cheap dentist's inept handling; studies to become a nurse; and how she lands a husband, Apolonio de Vera (Pol), a brilliant orthopedic surgeon from a wealthy Ilocano family in Vigan. They move to Milpitas, California, in the hope of a better life. However, their lives and social classes change as Paz becomes the breadwinner by working two nursing jobs while Pol works as a security guard.

The story then focuses on the protagonist, Hero (short for Geronima), Pol's niece, who trains as a doctor in the Philippines but drops out of medical school and joins the New People's Army, an armed guerilla wing of the Communist Party. She serves as a doctor of the party for ten years before she is captured and kept imprisoned. Her thumbs are later mutilated and her body scarred by cigarette burns. When she is released, Hero's parents disown her. Pol invites Hero to come to Milpitas on a tourist visa to live with them. Hero settles in and eventually overstays.

In America, Hero takes care of Pol's and Paz's eight-year-old daughter, Roni (also short for Geronima), by taking her to school. When she is not doing the driving, she keeps the house clean. Hero develops a close friendship with her niece and accompanies Roni on visits to Adela, the faith healer, who tries to cure her severe eczema. Adela also owns a restaurant, Boy's BBQ \& Karaoke. There, Hero meets Rosalyn, Adela's daughter, who does hair and makeup, and later begins a relationship with her. Hero and Rosalyn's friendship turns into a romance as they exchange manga comics and indie rock tapes. Hero also slowly becomes part of Rosalyn's tight circle of friends.

Hero's social life slowly blossoms and she manages to work the cash register at the strip-mall turo-turo ${ }^{3}$ restaurant. She wanders through gatherings and parties at strangers' houses, picking up men for one-night stands and sometimes women as well.

Rejected by her family and denied a place at home in the Philippines, Hero was left with no other choice than to leave the country and accept her uncle's offer to live in California. Does this make Hero a diasporic person or an exile? Diaspora 
is opted, whereas exile is enforced. Once in the United States, Hero negotiates aspects of her life. Hero struggles to remain true to some Philippine ways of life, such as loyalty to her family and respect for her elders, while also exploring other aspects that are accepted in America, such as her bisexuality.

The novel emphasizes how racial essentialism is still deep-seated in American society; however a diasporic person affiliates herself doesn't necessarily mean society will perceive her as she wishes to be seen. Hero is in fact not perceived as an American. She is an illegal alien when she overstays; she is Filipino among family and friends. Ethnicity should be examined as a question of perception and not in terms of naturalness since no person can effectively declare to be authentic if the recognition of her identity depends on another person. The same can be said of Hero's sexuality.

[I]dentity is viewed as strategic, rather than essential, contingent on, reproduced, decaying, co-opted, in relation to material and discursive factors that, especially in the context of sexualities, are always a complex lamination of local onto global onto local. Sexuality is not only essence, not timeless, it is also not fixed in place; sexuality is on the move. (Eppler and Patton 2)

I would like to analyze how Hero's sexual identity is constructed, so the reader can understand better how sexuality intersects with ethnicity in America Is Not the Heart. In America, Hero's body is more marked than in the Philippines. Rosalyn asks Hero if Roni's parents are treating her right (not knowing that Hero is Roni's aunt). Hero replies that they do. Rosalyn just wants to make sure that it is the truth and tells her:

Look, it's just-my mom has a cousin, she came over from the Philippines a couple of years ago, she didn't have papers either, and she started working as like a maid for some family down in Glendale and - they - they don't let her go out anywhere, they don't even let her go out of the house, she's only ever called us twice, and, it's not like she can do anything or they'll get her deported and-look. I just, you-you-you never come out except for with Roni and only then to see my grandma, you never come to the parties, you never go out on the weekends, it's like you're on house arrest or something-I don't know. (Castillo 161-162)

The clause "I don't know" makes possible that the perception of Hero as oppressed is wrong. Stories about exploited illegal aliens are not unique to the Filipino diasporic experience but this is played out nicely in the above excerpt. Indeed, it seems as if Rosalyn is trying to convince herself it might not be the case. Rosalyn does not know that Hero comes from a family of privilege in the Philippines. It would seem that Hero is constructed as the typical illegal alien because she does not socialize as 
expected. It is the same with her family, especially Pol who tells her that it is good she is making friends: "It's good for you" (Castillo 164)

It hadn't ever crossed her mind that she wasn't going out as much as a woman her age should, or would want to; it hadn't crossed her mind that someone would think she was being treated badly, held captive. She knew what it was like to be treated badly, held captive. She didn't know what her life looked like to other people. (Castillo 164)

It is only when she works at the restaurant when "[p]eople started to recognize Hero ... didn't say much, especially to Hero, and when they did, they spoke to her in English" (Castillo 166).

Hero's sexuality is also "seen" in terms of her ethnicity. When she starts socializing and attending parties with Rosalyn and her friends, they adopt a protective attitude towards her. The default assumption is that she is straight. For instance, Jaime finds her tucked away in a couch with Peter, a man she meets and is in drinking conversation with.

Hero did not know how long he'd been standing there before she registered his presence, looking down at Hero in disbelief, cigarette tucked behind his ear.

The hell? Rosalyn and Rochelle have been looking all over for you [ . . . J Jaime waited. Then turned and walked away. Then he stopped, spun around, came back, knelt down next to Hero, shouted into her ear: If you go home with him but want a pickup, page me 911. You got my number, right? (Castillo 199)

She is eventually accepted as someone who has sexual needs. Without knowledge of Hero's past, she is also perceived as heterosexual until she is observed to have a one-night stand with Vanessa, a Vietnamese American woman, and is confirmed a bisexual identity. She now possesses a marked identity for the others.

When the relationship between Hero and Rosalyn is brought out in the open on an occasion of the latter's drunkenness, Rosalyn tries to deny all her claims by distancing herself from Hero. Although in Hero's and Rosalyn's America, gay men and women go out on dates and even get married, in the suburb of Milpitas, the situation is completely different. Rosalyn herself cannot come out gay. Milpitas, like the Philippines itself, is at once a tight-knit community governed by traditions and a crossroads of conflicting cultures. The migrant residing there has to abide by the moral principles of the Catholic Church to maintain order. Also, the community is quite small.

The only negative was that if there were any girls who were maybe interested in putting their faces in between your legs, you never met them. Or there was an alarmingly

Kritika Kultura 35 (2020): 189-193 
high possibility the girls knew your family - had eaten barbecue or sung karaoke in your grandparents' restaurant, had worked at the hospital with your mom, had their house exorcised by your grandma. The gift of the small world was that it was small. The curse of the small world was that it was small. (Castillo 281)

Both Hero and Rosalyn experience the tension between the desire to live unmarked by sexuality and gender and the desire to be marked by these:

That's fuckin' easy for someone to say who, who-do you live here? Do you have to deal with seeing people who knew you when you were fucking ten years old coming into your place of work on a daily basis? Into your home? [ . . . ] no one thinks any different of you, but things are different for me ... but I have to be more careful. (Castillo 302)

If we examine the relationship between the two women from Rosalyn's perspective, ethnicity allies with sexuality in "validating" her and in testifying to her existence as a marked human being. Castillo chooses to have Rosalyn reveal her fear to Hero so as to convince the reader not to condemn her that easily. Granted, Rosalyn's confession is a writer's device, yet one still wonders why Rosalyn confides in Hero such critical details about her feelings. There is a certain appeal in her words, an appeal that can only come from a woman who cannot return to who she used to be.

Although Hero knows her bisexuality is not a scourge and she has never judged herself as less than a woman, her sexuality becomes a deliverance at this point in the novel. It increases her chances of finding long-lasting love. It urges her up the couples' path. More significantly, sexuality here is the necessary condition-the "only if" equation-that allows a complete exchange. As filtered through Hero's eyes, the Filipino diaspora is complicatedly resistant to belonging, fragmented with many of the similar domestic divisions of class, gender, and religion that symbolize life in the Philippines.

\section{CONCLUSION}

Both novels illustrate diaspora as an ideological construct that needs to be interrogated. Narratives of diaspora are not limited to issues of nationality and ethnicity alone. They are intrinsically linked to questions that are discussed in this paper-religion, sexuality, and class. Clearly, as America is more tolerant of class, ethnic, and sexual identities, it is relatively easy for diasporic citizens like Hero to blend into the American mainstream though she also needs to negotiate the politics that attempt to contain Filipinos within its own separate community in America. If we accept the idea of diaspora as a provisional state, then we know that 
the ways and means different diasporic characters navigate their identity modalities with those they encounter, cannot simply be fixed as static. In a global community where experiences of diasporic individuals are provisional, we are able to explore more attentively how diaspora changes and continues to change its nature and disrupts stable constructs of identity. The journeys of Ben and Hero-and even those of some of the other diasporic characters-uncover new power relations if we contextualize their experiences within their time and place. The danger of looking at diasporic experience as provisional may lessen the importance of larger historical conditions for the movement of people across nations as a whole exists; however, it is only through the provisional that we can avoid homogenizing experiences and instead highlight the particularities of diaspora. 


\section{Notes}

1. Refer to Table 1.1 in Robin Cohen's Global Diasporas: An Introduction, Routledge, 1997, p. 26.

2. Religion that offers only one interpretation of the events in the Bible.

3. This literally translates as "point-point" in English. This refers to an eatery where a customer points to a dish he or she wants to order.

Kritika Kultura 35 (2020): 192-193

(c) Ateneo de Manila University

<http://journals.ateneo.edu/ojs/kk/> 


\section{Works Cited}

Bacho, Peter. Cebu. U of Washington P, 1991.

Basch, Linda, et al. Nations Unbound: Transnational Projects, Postcolonial Predicaments, and Deterritorialized Nation-States. Gordon and Breach, 1994.

Brah, Avtar. Cartographies of Diaspora: Contesting Identities. Routledge, 1996.

Castillo, Elaine. America Is Not the Heart. Viking, 2018.

Chuh, Kandice. "Imaginary Borders." Orientations: Mapping Studies in the Asian Diaspora, edited by Kandice Chuh and Karen Shimakawa, Duke UP, 2001, pp. 277-295.

Cohen, Robin. Global Diasporas: An Introduction. Routledge, 1997.

Evans Braziel, Jana, and Anita Mannur. Theorizing Diaspora: A Reader. Blackwell, 2003.

Dufoix, Stéphane. Diasporas. U of California P, 2008.

Goh, Robbie, and Shawn Wong. Asian Diasporas: Cultures, Identities, Representations. Hong Kong UP, 2004.

Lowe, Lisa. Immigrant Acts: On Asian American Cultural Politics. Duke UP, 1996.

Ong, Aihwa. Flexible Citizenship: The Cultural Logics of Transnationality. Duke UP, 1999.

Patterson, Christopher. "The Filipino American in Spaces of Liberal Tolerance: Satire and Reciprocity in Peter Bacho's Cebu." MELUS: Multi-Ethnic Literature of the United States, vol. 39, no. 1, Spring 2014, pp. 149-172.

Safran, William. "Deconstructing and Comparing Diasporas." Diaspora, Identity and Religion: New Directions in Theory and Research, edited by Waltraud Kokot, et al., Routledge, 2004, pp. 9-29.

Sanchez Eppler, Benigno, and Cindy Patton. Queer Diasporas. Duke UP, 2000.

Stefani, Debora. "Resisting Diaspora and Transnational Definitions in Monique Truong's The Book of Salt, Peter Bacho's Cebu and Other Fiction," Dissertation, Georgia State U 2012.

Vertovec, Steven. Transnationalism. Routledge, 2009.

Kritika Kultura 35 (2020): 193-193

(c) Ateneo de Manila University 